\section{Commentary: Even simplified, it is still a commando operation}

\author{
Luca Weltert, MD, ${ }^{\mathrm{a}}$ and Mario Gaudino, MD, $\mathrm{MSCE}^{\mathrm{b}}$
}

The inner scaffolding of the heart, known as the fibrous skeleton, is the structure that surgeons rely on to provide good anchoring when performing surgery on valves. The intervalvular fibrosa (IVF) is the fibrous structure between the lateral and medial fibrous trigones that connects the base of the anterior mitral leaflet to the aortic annulus and aortic valve. Toward the aorta, the IVF connects to the noncoronary cusp on the right and to the left coronary cusp on the left, with the left coronary-noncoronary commissure in the middle, and posteriorly, the dome of the left atrium is attached to the IVF.

Destruction of the IVF typically occurs in infective endocarditis, owing to enzymatic degradation with a preference for connective tissue. To make things more difficult for both the patient and the surgeon, it usually occurs when prosthetic valves in the mitral and/or aortic positions are infected.

Up until the 1990s, this condition was considered inoperable, until radical debridement of infected tissue and foreign material, including all or part of the IVF, was attempted. Radical debridement followed by reconstruction of the IVF was first published by David and colleagues in 1997. ${ }^{1}$ This procedure proved so technically challenging that it was nicknamed the "commando operation."

Today, as patients presenting for surgery are becoming older and sicker, reconstruction of the IVF also may be required in patients without infective endocardidits with severe degenerative calcification or in those who have undergone previous valve operations and do not have adequate

From the ${ }^{\mathrm{a}}$ Division of Cardiac Surgery, European Hospital, Rome, Italy; and ${ }^{\mathrm{b}}$ Department of Cardiothoracic Surgery, Weill Cornell Medicine, New York, NY.

Disclosures: The authors reported no conflicts of interest.

The Journal policy requires editors and reviewers to disclose conflicts of interest and to decline handling or reviewing manuscripts for which they may have a conflict of interest. The editors and reviewers of this article have no conflicts of interest.

Received for publication Aug 30, 2020; revisions received Aug 30, 2020; accepted for publication Sept 5, 2020; available ahead of print Sept 15, 2020.

Address for reprints: Mario Gaudino, MD, MSCE, Department of Cardiothoracic Surgery, Weill Cornell Medicine, 525 East 68th St, New York, NY 10065 (E-mail: mfg9004@med.cornell.edu).

JTCVS Techniques 2020;4:104-5

2666-2507

Copyright (c) 2020 The Authors. Published by Elsevier Inc. on behalf of The American Association for Thoracic Surgery. This is an open access article under the CC BY-NCND license (http://creativecommons.org/licenses/by-nc-nd/4.0/).

https://doi.org/10.1016/j.xjtc.2020.09.010

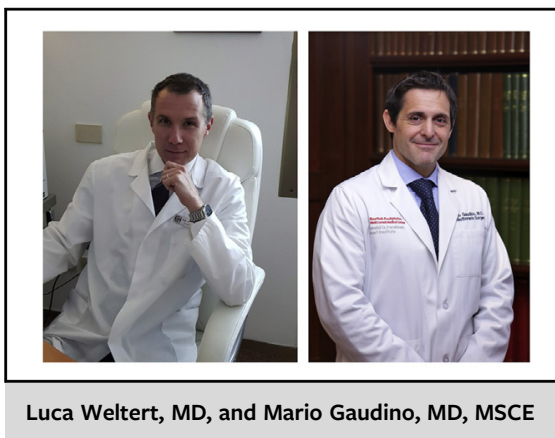

CENTRAL MESSAGE

Disruption of the fibrous skeleton, usually due to infective endocarditis, remains a challenging situation. Recently, simplifications of the original commando procedures have been proposed.

residual tissue to which to secure the new prosthesis. In this setting, IVF procedures are an option, allowing enlargement of both the mitral and aortic annuli for implanting larger prostheses. ${ }^{1-5}$

Although the results of this heroic surgery have improved over the years, the operative risk remains considerable, with operative mortality ranging from $6.7 \%$ to $32 \%$ and a 1 -year mortality as high as $52 \% .{ }^{6}$ Recent efforts have been made to simplify the operation by using prostheses that incorporate extra tissue to aid suture anchoring instead of cryopreserved homografts and by providing less extensive access to the cardiac chambers. ${ }^{7,8}$

In this issue of the Journal, Elde and coauthors ${ }^{9}$ propose an interesting iteration of both approaches, and the results seem promising. In their approach, both valves were replaced via an aortotomy without the need to open the dome of the left atrium, the aortic bioprosthetic valve was sewn into an hemashield graft, and the aortic valve sewing ring was secured to the remaining left ventricular outflow tract and to the sewing ring of the mitral bioprosthesis.

Although this approach remains a procedure requiring full mastery of structural heart valve reconstructive surgery, the path to its wider practicability is clear.

\section{References}

1. David TE, Kuo J, Armstrong S. Aortic and mitral valve replacement with reconstruction of the intervalvular fibrous body. J Thorac Cardiovasc Surg. 1997;114: 766-72. 
2. De Oliveira NC, David TE, Armstrong TE, Ivanov J. Aortic and mitral valve replacement with reconstruction of the intervalvular fibrous body: an analysis of clinical outcomes. J Thorac Cardiovasc Surg. 2005;129:286-90.

3. Kim SW, Park PW, Kim WS, Sung K, Lee YT, Jun T-G, et al. Long-term results of aortomitral fibrous body reconstruction with double-valve replacement. Ann Thorac Surg. 2013;95:635-41.

4. Davierwala PM, Binner C, Subramanian S, Luehr M, Pfannmueller B, Etz C, et al. Double valve replacement and reconstruction of the intervalvular fibrous body in patients with active infective endocarditis. Eur J Cardiothorac Surg. 2014;45:146-52.

5. Navia JL, Al-Ruzzeh S, Gordon S, Fraser T, Aguero O, Rodriguez L. The incorporated aortomitral homograft: a new surgical option for double valve endocarditis. J Thorac Cardiovasc Surg. 2010;139:1077-81.
6. Pettersson GB, Hussain ST, Ramankutty RM, Lytle BW, Blackstone EH. Reconstruction of fibrous skeleton: technique, pitfalls and results. Multimed Man Cardiothorac Surg. 2014;2014:mmu004. https://doi.org/10.1093/mmcts/mmu004.

7. Hamasaki A, Uchida T, Kuroda Y, Sadahiro M. Modified commando operation using stentless aortic bioprosthesis in a patient with severe aortic annular destruction owing to massive infective endocarditis. Multimed Man Cardiothorac Surg. 2019; https://doi.org/10.1510/mmcts.2019.040.

8. Misfeld M, Davierwala PM, Borger MA, Bakhtiary F. The "UFO" procedure. Ann Cardiothorac Surg. 2019;8:691-8.

9. Elde S, de Biasi A, Woo YJ, Burton E. A novel alternative to the commando procedure: constructing a neo-aortic root by anchoring to the sewing ring of the replaced mitral valve. J Thorac Cardiovasc Surg Tech. 2020;4:101-2. 